\begin{tabular}{c|c|c}
\hline \hline & MARINE ECOLOGY PROGRESS SERIES \\
Vol. 214: 289-298, 2001 & Mar Ecol Prog Ser & Published April 26 \\
\hline
\end{tabular}

\title{
Seabird attraction to fishing vessels is a local process
}

\author{
Henrik Skov*, Jan Durinck \\ Ornis Consult A/S, Vesterbrogade 140, 1620 Copenhagen V, Denmark
}

\begin{abstract}
Seabird aggregation and scavenging around fishing vessels is widely assumed to be a major component of seabird ecology. However, few field data have shown the relative importance of human fishing activities in comparison with the distribution of marine habitats and the availability of natural food sources. Here we perform a spatial analysis of the relative influence of fishing activities, by modelling observed density gradients of working trawlers and attracted seabirds along PCAderived large scale gradients in hydrographic variables and abundance of small herring Clupea harengus, from shallow estuarine waters to deep oceanic waters across the Baltic Sea-North Sea interface. All hydrographic and biological data, including numbers of attracted seabirds, were collected synoptically from a ship sampling systematically throughout the region. The analysis indicates that a relatively small degree of overlap exists between the spatial distribution of fishing vessels and that of potentially scavenging seabirds. Gradients in the abundance of seabirds attracted to the ship indicate responses to hydrographic features such as upwelling zones and fronts, and gradients in the supply of natural foods such as schools of immature herring, rather than responses to changes in the supply of discards from fishing vessels. Estimates of the scale of attraction of seabirds by the research ship further indicate that attraction in the Baltic Sea-North Sea gradient is a local $(<10 \mathrm{~km})$ process. The small-scale nature of the attraction of seabirds to ships in the region is further tested by displaying observations of trawlers and attracted seabirds obtained from separate cruises in relation to observed salinity and pycnocline characteristics. We suggest that in similar heterogeneous environments at least, attraction of seabirds by trawlers is predominantly a result of local processes. Our results illustrate that the importance of human fisheries in seabird ecology cannot be assessed without detailed knowledge of seabirds' dependence on natural food sources and habitats.
\end{abstract}

KEY WORDS: Fisheries $\cdot$ Seabird habitats $\cdot$ Discards $\cdot$ Oceanography $\cdot$ Northwest European Shelf Resale or republication not permitted without written consent of the publisher

\section{INTRODUCTION}

Although seabird attraction to commercial trawlers discarding fish waste is a frequent sight in many of the world's oceans, the relative importance of this process in the ecology of seabird communities remains poorly understood. A number of studies on seabird distribution and abundance in relation to trawlers have documented that trawling activities world-wide can attract large numbers of seabirds, and may generate im-

\footnotetext{
*E-mail: hs@ornisconsult.dk
}

portant foods for several species (eg. Boswall 1960, Abrams 1985, Hudson \& Furness 1988, Thompson 1992, Camphuysen et al. 1995a). In areas such as the North Sea, these so-called 'scavengers' have been reported to make intensive use of discarded matter (Hudson \& Furness 1988, Garthe 1993, Camphuysen et al. 1995a). These observations have raised widespread concerns regarding the impact of general reductions in fish waste, or increases in mesh size, on seabird populations (Furness 1992, Garthe et al. 1996). However, although scavenging seabirds have often been treated as dietary guilds mainly exploiting waste products from human fishing activities (Abrams 1985, Furness 
1992, Camphuysen et al. 1995a), the total populations of potential scavengers at sea seem to exceed the populations recorded in proximity to fishing trawlers (Tasker \& Becker 1992, Camphuysen et al. 1993).

Scavenging species may make only secondary use of discards and offal provided by fisheries. Brown (1970) documented that in spite of the large numbers of fulmars Fulmarus glacialis frequently recorded at trawlers in Newfoundland waters, their distribution was primarily controlled by oceanographic features; Camphuysen \& Garthe (1997) came to the same conclusions for the North Sea on the basis of year-round studies. Camphuysen et al. (1995b) showed that gannets Sula bassana from the breeding colony at Bass Rock, eastern Scotland, largely ignore fishing vessels while feeding on herring Clupea harengus at large distances from the colony.

Commercial fishing activities in north-western Europe are focussed on shelf and shelf break regions, environments characterised by heterogeneity and offering multiple natural food sources for seabirds. The role of fisheries as a component of seabirds' habitat has never been satisfactorily resolved in these environments. This is mainly due to the heterogeneity of food supplies, the scarcity of data on seabirds' use of natural food sources outside the breeding season and in offshore waters, and the wide ranging distributions of both seabirds and fishing vessels. Accordingly, estimated rates of consumption of discarded fish and offal by seabirds have so far relied on 2 assumptions (Hudson \& Furness 1988, Camphuysen et al. 1995a, Garthe et al. 1996): (1) natural food sources comprise a minor proportion of the diet of the species in question; and, (2) a specific utilisation rate is unrelated to the marine habitat where the fishery is undertaken.

Given that comprehensive dietary data on natural food sources in offshore waters are lacking for all potential scavengers in the region, formal tests of the first assumption are currently unfeasible. The data available from coastal environments indicate that the role of discards and offal in the diet of potential scavengers varies considerably between species and breeding colonies: from negligible to supplementary (mainly during periods of low availability of natural prey) to highly important (Hamer et al. 1991, Walsh et al. 1991, Camphuysen et al. 1995a, Oro et al. 1995a). The potential bias introduced by the second assumption is equally large, as estimates of rates of seabird consumption of fish waste are made over extremely large areas $\left(>10^{5} \mathrm{~km}^{2}\right.$; Camphuysen et al. 1995a, Garthe et al. 1996), disregarding oceanographic or other habitat boundaries. We tested the second assumption by comparing the spatial distribution of fishing vessels and seabirds scavenging at a stationary research vessel across strong habitat boundaries in the
North Sea and Baltic Sea, and by assessing the scale over which the attraction to fishing vessels occurs in these regions. The dispersal of non-breeding seabirds in the North Sea and the Baltic Sea has been well established through extensive recent mapping programmes (see overviews in Durinck et al. 1994, Skov et al. 1995, Laursen et al. 1997). The fishing fleets operating in the North Sea and the Baltic Sea are engaged in demersal and pelagic fisheries, which produce large amounts of discards and offal. This made it possible to compare gradients in the number of seabirds attracted to the research vessel and observed trawlers across strong physical oceanographic gradients throughout the region. The test assumes higher number of scavengers in areas with high rates of discard, and hence a positive correlation between trawler density and abundance of attracted seabirds.

\section{MATERIALS AND METHODS}

Study area. The study area was the salinity gradient between the Baltic Sea and the North Sea, as well as high- and low-saline waters west and east of the gradient. The main sampling activity took place within a region stretching between $03^{\circ} 00^{\prime} \mathrm{E}$ and $11^{\circ} 00^{\prime} \mathrm{E}$ (Fig. 1). The surface salinity ranges from 34 to $35 \mathrm{psu}$ in the North Sea to 30 to 34.5 psu in the Skagerrak, 8 to $30 \mathrm{psu}$ in the Kattegat and 7 to $8 \mathrm{psu}$ in the Baltic proper (Lee 1980, Kullenberg 1981). In addition to the surface gradient, the major part of these regions is characterised by a strong vertical halocline, which in parts of the Kattegat and the Skagerrak takes the form of an extensive shallow pycnocline (Hognestad 1987). Four to five currents run eastwards from the North Sea into the Skagerrak on the Danish shelf, while a westward current runs from the Baltic to the North Sea over the Norwegian shelf. The extent of the sub-surface waters of the Kattegat and the Baltic proper are affected by the inflow/outflow rates of these currents. The local distribution of surface water in the different parts of the region is generally determined by the wind regime and the Coriolis force. The depths in the region vary greatly, from less than 20 m over the large coastal plains in the German Bight, the western Kattegat and the southern Baltic, to the mid-shelf zone of 20 to $100 \mathrm{~m}$ found throughout the majority of the region, to the outer shelf, shelf break and deeper zone of 100 to $500 \mathrm{~m}$ found in the northern North Sea, the Skagerrak, the northern Kattegat and the Baltic proper.

Data collection. Modelling of the scale of attraction to the ship and spatial variation of trawlers and attracted seabirds was based on data collected during 4 cruises in February-March 1990-1993. These data were considered relatively homogenous, as they were 

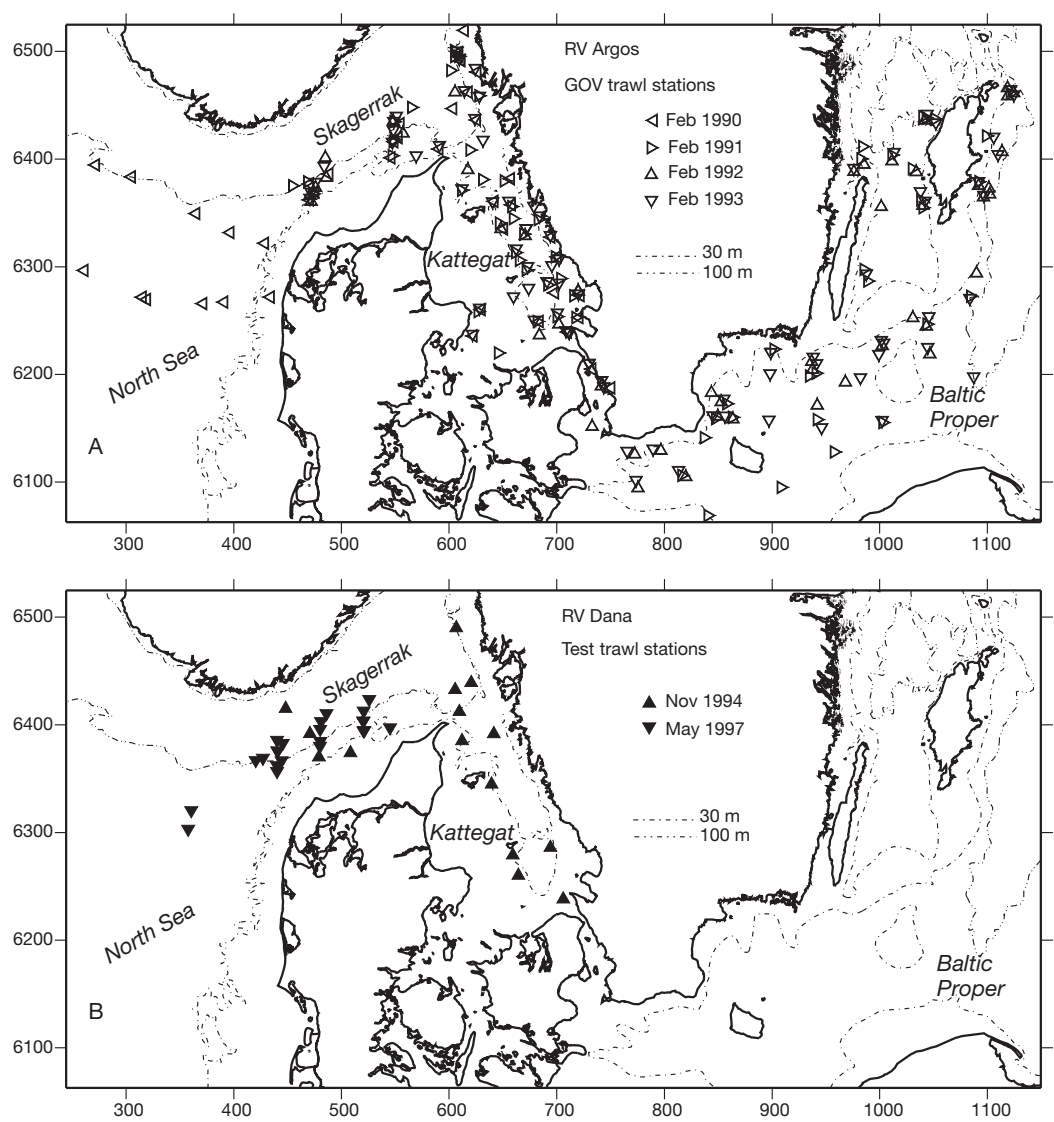

Fig. 1. Distribution of stations used (a) in modelling attraction distances and spatial variability of potential avian scavengers, and (b) for model verification were attracted using standardised samples of small $(<10 \mathrm{~cm})$ clupeids mixed with popcorn and sawdust.

Line transect counts of seabirds at sea and working trawlers were made while steaming between stations at a speed of 8 to 10 knots. Line transect data were split into time periods of $10 \mathrm{~min}$ (equivalent to ca $3 \mathrm{~km}$ ). Trawlers were recorded in the count period, when they were at the closest range from the research ship. During the RV 'Argos' cruises trawlers were recorded within a distance of 1 mile from the ship. During the test cruise in November 1994, trawlers were recorded at the station by radar within a distance of $3 \mathrm{n}$ mile (see Camphuysen et al. 1995a for details), and during the test cruise in May 1997 they were recorded within a distance of $2 \mathrm{n}$ mile from the station.

The local abundance of seabirds at sea was recorded from the bridge wing by an observer, using the methods described by Tasker et al. (1984) and Webb \& Durinck (1992). A transect width of $300 \mathrm{~m}$ was operated within a $90^{\circ}$ sector. Birds seen farther away than $300 \mathrm{~m}$ or on the other side of the survey ship were ignored, thereby ensuring a high recording efficiency within the counting zone.

Observations were halted at Beaufort sea states higher than 6 . To ensure correct delimitation of the transect, range finders were used. Correction for undetected birds away from the centreline was made by calculating the proportion of birds recorded within the transect using the half-normal function in the DISTANCE software package (Laake et al. 1993).

Hydrographic data. The distribution of wintering seabirds in the study region is profoundly influenced by the strong gradients in surface salinity, pycnocline depth and water depth (Durinck et al. 1990, Laursen et al. 1997, Skov \& Durinck 1999). Synoptic data on surface salinity, pycnocline depth and water depth were taken at the trawl stations. Salinity was measured on board RV 'Argos' with an AGE 2100 Salinometer (Ottawa, Canada), and onboard RV 'Dana' with a Neil Brown (Mark III) CTD.

Fish data. During winter, the community of small fish in the Kattegat and Skagerrak is dominated by young herring, which is a key prey item for many species of seabirds wintering in the region (Madsen 1957, Durinck et al. 1991, Skov et al. 2000). Synoptic data on the density (number per trawl hour) of small herring 
$(<20 \mathrm{~cm})$ were taken at the trawl stations according to standard methods and procedures described elsewhere (Anon. 1992, ICES 1996). The potential for data collected by GOV trawl to display spatial patterns of juvenile clupeids has been shown by Munk \& Christensen (1990).

Analysis and data interpretation. The following statistics on attracted seabirds and working trawlers were computed using data from the RV 'Argos' cruises. In order to evaluate the stability of the species composition of attracted seabirds at the ship, inter-specific correlations were determined by Spearman rank correlation analysis. In order to determine the scale over which the attraction to fishing vessels occurs we compared the numbers of attracted seabirds at the trawl station with the local densities obtained outside the trawl station (line transect counts). The attraction radius was estimated by: $\sqrt{ }($ attraction area/ $\pi$ ), assuming equal attraction from all directions around the ship. The attraction area was estimated by dividing the specific number attracted with the local density, which was obtained within the distance of $25 \mathrm{~km}$ to the trawl station. A GIS-based buffer analysis routine (Microstation PC) was applied in order to calculate mean densities recorded within a radius of $25 \mathrm{~km}$ from each trawl station. To verify the relationship between the number of seabirds attracted to the ship and local densities at sea, Spearman rank correlation analysis was performed at the scale of $25 \mathrm{~km}$.

The strength of the spatial relationship between abundances of attracted seabirds and working trawlers was tested by Pearson correlation analysis and by displays of abundance data on oceanographic gradients derived from principal component analysis (PCA) of the synoptic data on surface hydrography, water depth and abundance of young herring. The assumption of a positive correlation between trawler density and abundances of attracted seabirds at the research ship may become biased during situations where large quantities of fish waste are discarded from trawlers located within the attraction distance to the research ship. To reduce this bias the correlation analysis and PCA were carried out using data averaged at a scale of $15^{\prime} \mathrm{N} \times 30^{\prime} \mathrm{E}$.
Trends in spatial overlap between potential scavengers and trawlers, indicated by the displays on the first and second PCA axes, were tested by plotting data on attracted birds and trawlers, collected during the RV 'Dana' cruises, in relation to the ranges of synoptic hydrographic data. During the test cruise in May 1997, detailed data on pycnocline topography were collected in the Skagerrak synoptically with recordings of trawlers and attracted sea birds.

\section{RESULTS}

Counts of attracted seabirds were made at a total of 275 stations and samples of the abundance of seabirds at sea and working trawlers were made along a total of $3780 \mathrm{n}$ mile of line transects (Fig. 1, Table 1).

The composition of seabird aggregations at the ship varied both between and within years (Table 2). The analysis of inter-specific correlations stressed that the relative abundance of species was not consistent in these aggregations (Table 3). A big difference in the spatial variability of trawlers and attracted seabirds was found in the North Sea-Baltic Sea interface. Trawlers were mainly recorded working in shelf waters, the highest frequencies of trawlers being found in upper shelf waters west of Denmark, in several places in the Kattegat and in the western Baltic Sea. Few trawlers were observed in the deeper waters of the Norwegian Trench. Fulmars attracted to the ship

Table 1. Cruise details showing number of stations and length of transect between stations. Cruises 1 to 4 used for modelling distributions of trawlers and potential scavengers; cruises 5 and 6 used for model testing

\begin{tabular}{|lcc|}
\hline Cruise & No. of stations & Length of transect $(\mathrm{km})$ \\
\hline RV 'Argos' & & \\
(1) Feb-Mar 90 & 63 & 1930 \\
(2) Feb 91 & 44 & 1440 \\
(3) Feb-Mar 92 & 49 & 1425 \\
(4) Feb-Mar 93 & 81 & 1333 \\
RV 'Dana' & & \\
(5) Nov 94 & 15 & 475 \\
(6) May 97 & 23 & 396 \\
\hline
\end{tabular}

Table 2. Mean and maximum numbers and proportions of seabirds recorded at trawl stations during RV 'Argos' cruises 1990-93

\begin{tabular}{|c|c|c|c|c|c|c|c|c|c|c|}
\hline \multirow[t]{2}{*}{ Year } & \multicolumn{2}{|c|}{ Fulmar } & \multicolumn{2}{|c|}{ Common gull } & \multicolumn{2}{|c|}{ Herring gull } & \multicolumn{2}{|c|}{ Great black-backed gull } & \multicolumn{2}{|c|}{ Kittiwake } \\
\hline & Mean / \% & $\operatorname{Max} / \%$ & Mean / \% & $\operatorname{Max} / \%$ & Mean / \% & $\operatorname{Max} / \%$ & Mean / \% & $\operatorname{Max} / \%$ & Mean / \% & $\operatorname{Max} / \%$ \\
\hline 1990 & $0.7 / 1.0$ & $21 / 27.3$ & $4.2 / 6.2$ & $60 / 66.7$ & $44.5 / 67.6$ & $500 / 100$ & $11.3 / 15.5$ & $102 / 82.3$ & $6.7 / 8.1$ & $132 / 64.1$ \\
\hline 1991 & $0.2 / 0.5$ & $7 / 16.3$ & $4.5 / 13.4$ & $41 / 100$ & $32.2 / 65.7$ & $190 / 95.0$ & $7.4 / 15.4$ & $60 / 57.1$ & $1.3 / 5.0$ & $12 / 50.0$ \\
\hline 1992 & $7.0 / 2.2$ & $150 / 27.2$ & $7.1 / 7.2$ & $100 / 61.9$ & $140.1 / 74.7$ & $1000 / 100$ & $14.9 / 9.6$ & $200 / 100$ & $23.9 / 6.3$ & $320 / 79.4$ \\
\hline 1993 & $0.5 / 1.9$ & $10 / 100$ & $5.0 / 5.8$ & $50 / 83.3$ & $124.9 / 72.0$ & $700 / 98.4$ & $20.3 / 12.7$ & $250 / 68.8$ & $6.5 / 6.4$ & $115 / 66.7$ \\
\hline
\end{tabular}


Table 3. Inter-specific correlations for seabirds recorded during the RV 'Argos' cruises 1990-93 ( $\left.{ }^{*} \mathrm{p}<0.01,{ }^{* *} \mathrm{p}<0.001\right)$

\begin{tabular}{|lrccc|}
\hline & Fulmar & $\begin{array}{c}\text { Common } \\
\text { gull }\end{array}$ & $\begin{array}{c}\text { Herring } \\
\text { gull }\end{array}$ & $\begin{array}{c}\text { Great black- } \\
\text { backed gull }\end{array}$ \\
\hline $\mathbf{1 9 9 0}$ (df 61) & & & & \\
Common gull & -0.098 & & & \\
Herring gull & 0.031 & 0.196 & & \\
Great black-backed gull & 0.259 & -0.083 & 0.010 & 0.071 \\
Kittiwake & 0.042 & $0.400^{*}$ & 0.086 & \\
$\mathbf{1 9 9 1}$ (df 42) & & & & \\
Common gull & -0.099 & & & \\
Herring gull & -0.004 & 0.109 & & \\
Great black-backed gull & -0.104 & 0.006 & $0.927^{* *}$ & \\
Kittiwake & -0.084 & -0.220 & -0.053 & \\
$\mathbf{1 9 9 2}$ (df 47) & & & & \\
Common gull & -0.110 & & & \\
Herring gull & 0.169 & 0.291 & & \\
Great black-backed gull & 0.114 & 0.323 & 0.117 & \\
Kittiwake & $0.849 *$ & -0.093 & 0.121 & \\
1993 (df 79) & & & & 0.269 \\
Common gull & -0.048 & & & \\
Herring gull & -0.003 & 0.179 & & \\
Great black-backed gull & -0.011 & 0.096 & $0.481^{* *}$ & \\
Kittiwake & 0.005 & 0.052 & $0.438^{* *}$ & \\
& & & & \\
\hline
\end{tabular}

all species, being smallest for fulmar $(<3 \mathrm{~km})$ and common gull $(<4.4 \mathrm{~km})$ and largest for herring gull $(<8.5 \mathrm{~km})$ and great black-backed gull (<5.8 km, Fig. 2).

The correlation between attracted seabirds and local densities of trawlers was not significant $(\mathrm{p}>0.01)$ for all study species during all 4 surveys. The principal component analysis summarised the synoptic oceanographic data efficiently. The first and second axes, which account for $78 \%$ of the standardised variance, illustrate the main variation in hydrography, from shallow shelf and estuarine water masses to shelf break areas and water masses with higher salinity, and the variation in abundance of young herring respectively. When displayed on these 2 major gradients, trawlers and attracted seabirds also showed limited spatial overlap (Fig. 3). The observed dispersal of trawlers was apparently not related to 1 of the 2 PCA axes; a continous zone of were confined to areas of higher salinity in the Skagerrak and the North Sea, and no birds were observed in the half of the region with surface salinities below 32 psu (inner German Bight, Kattegat, Baltic Sea). Maximum numbers of attracted fulmars occurred at the shelf break and in deeper waters in the central Skagerrak. Common gulls were attracted in all waters, yet the largest numbers were observed in estuarine waters in proximity to coastal areas of the German Bight, Kattegat and western Baltic Sea. Herring gulls were also seen throughout the region at the ship, but large numbers of this species predominated in the easternmost part of the region in the Bornholm Basin, in the southern and eastern Kattegat and in midshelf waters of the Skagerrak. The distribution of attracted great black-backed gulls resembled the distribution of herring gulls in the Kattegat, yet the largest numbers of great black-backed gulls were recorded off the Swedish Skagerrak coast. The range of attracted kittiwakes spanned most of the study region in the North Sea, Skagerrak and Kattegat, but no birds were attracted in the areas with surface salinities below 20 psu (Belt Sea, Baltic Sea). The largest numbers of kittiwakes were seen in the midshelf waters in the Skagerrak-Kattegat of 20 to $40 \mathrm{~m}$ depth.

The analysis of association between seabirds attracted to the ship and seabirds recorded outside trawling stations showed significant correlations for all 5 seabird species $(\mathrm{p}<0.01, \mathrm{n}=303)$ at the scale of $25 \mathrm{~km}$. The estimated attraction distances were relatively small for

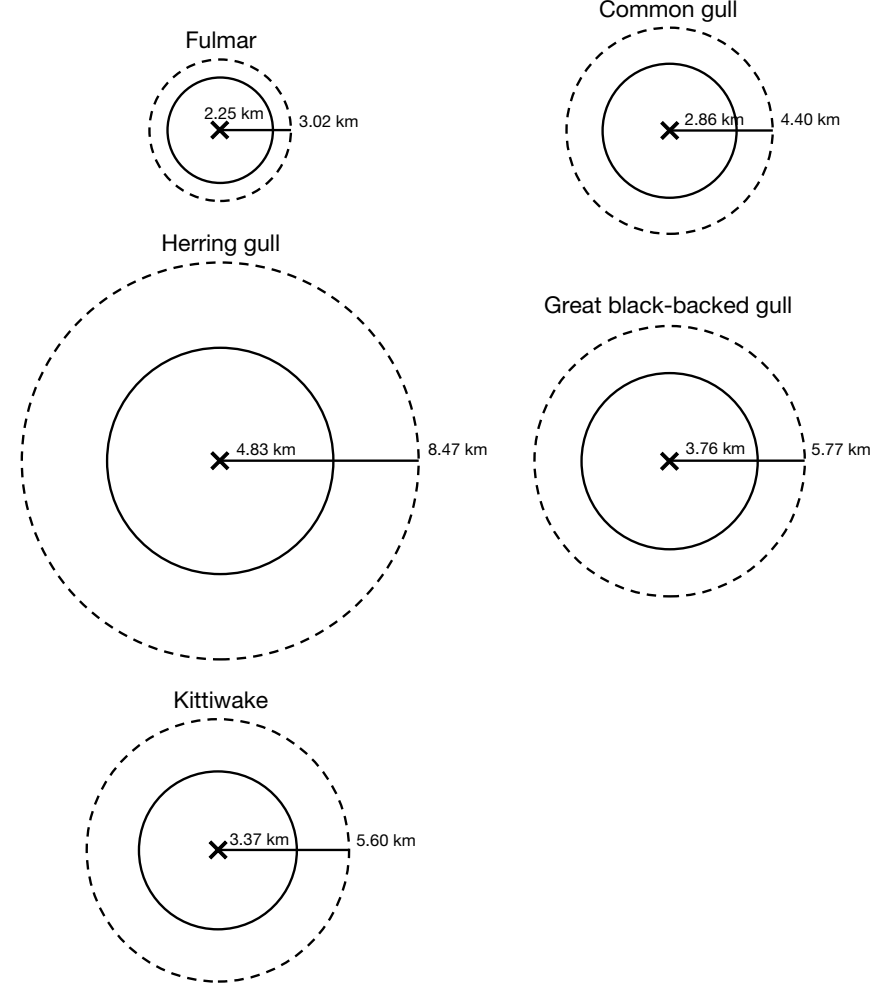

Fig. 2. Estimates of the average distance over which scavenging seabirds were attracted to the ship. Standard errors are indicated by dotted lines. Average distance of attraction for a given species is estimated from the number of scavenging individuals and the average density of birds within $25 \mathrm{~km}$ of the trawler, assuming equal attraction from all directions 

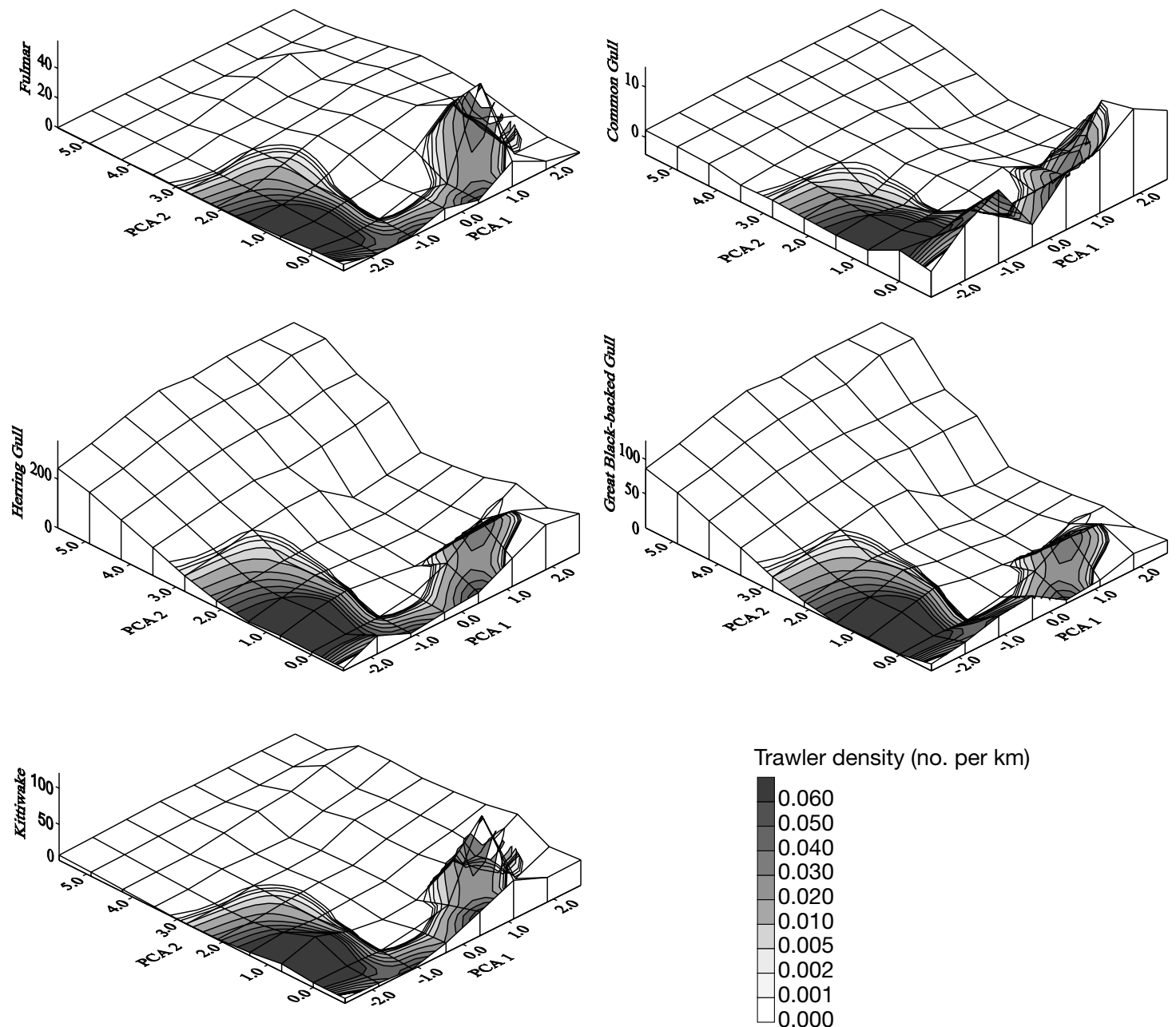

Fig. 3. Spatial variation of fulmars, common gulls, herring gulls, great black-backed gulls and kittiwakes attracted to the ship and active trawlers, in relation to oceanographic gradients in the Skagerrak-Kattegat. Oceanographic gradients are represented by PCA1 (estuarine-saline gradient) and PCA2 (gradient in young herring Clupea harengus abundance)

higher densities of trawlers spanned the lower and middle ranges of PCA1 as well as PCA2. Variation in the number of attracted fulmar and kittiwake were mainly associated with the hydrographic axis (PCA1), and both species showed peak abundances in a narrow zone of the upper range of the PCA1 axis. The number of attracted herring gull and great blackbacked gull seemed mainly associated with the abundance of herring (PCA2), the largest numbers of both species being seen in the upper range of PCA2 across the whole range of the hydrographic axis. The number of common gulls was not clearly related to any of the 2 PCA axes, as the highest numbers were seen in the lower range of $\mathrm{PCA} 2$ and over the whole range of PCA1.

The comparisons of results obtained in the 2 test scenarios suggests only coincidence between trawlers and numbers of seabirds attracted to the research ship
(Figs. 4 \& 5). On the RV 'Dana' cruise in November 1994, trawlers were observed in 3 areas of the Kattegat and 2 areas of the Skagerrak, yet the observed patterns of the study species attracted to the ship were not consistent within these areas. The number of attracted fulmars was strongly related to surface salinity, as no birds were attracted in low salinity waters, and peak numbers were confined to high salinity (>33.5 psu) areas, where no trawlers were observed. Peak numbers of common gulls were recorded in the low salinity region between 23.0 and 24.5 psu in the southeastern Kattegat, overlapping with 2 of the trawler areas in the Kattegat, but not with the third area in the more saline northern Kattegat, or with the 2 areas in the Skagerrak. The observed patterns of attracted herring gulls and great black-backed gulls were rather similar. Both species were attracted to the ship throughout the study area. As for the common gull, the largest numbers of 

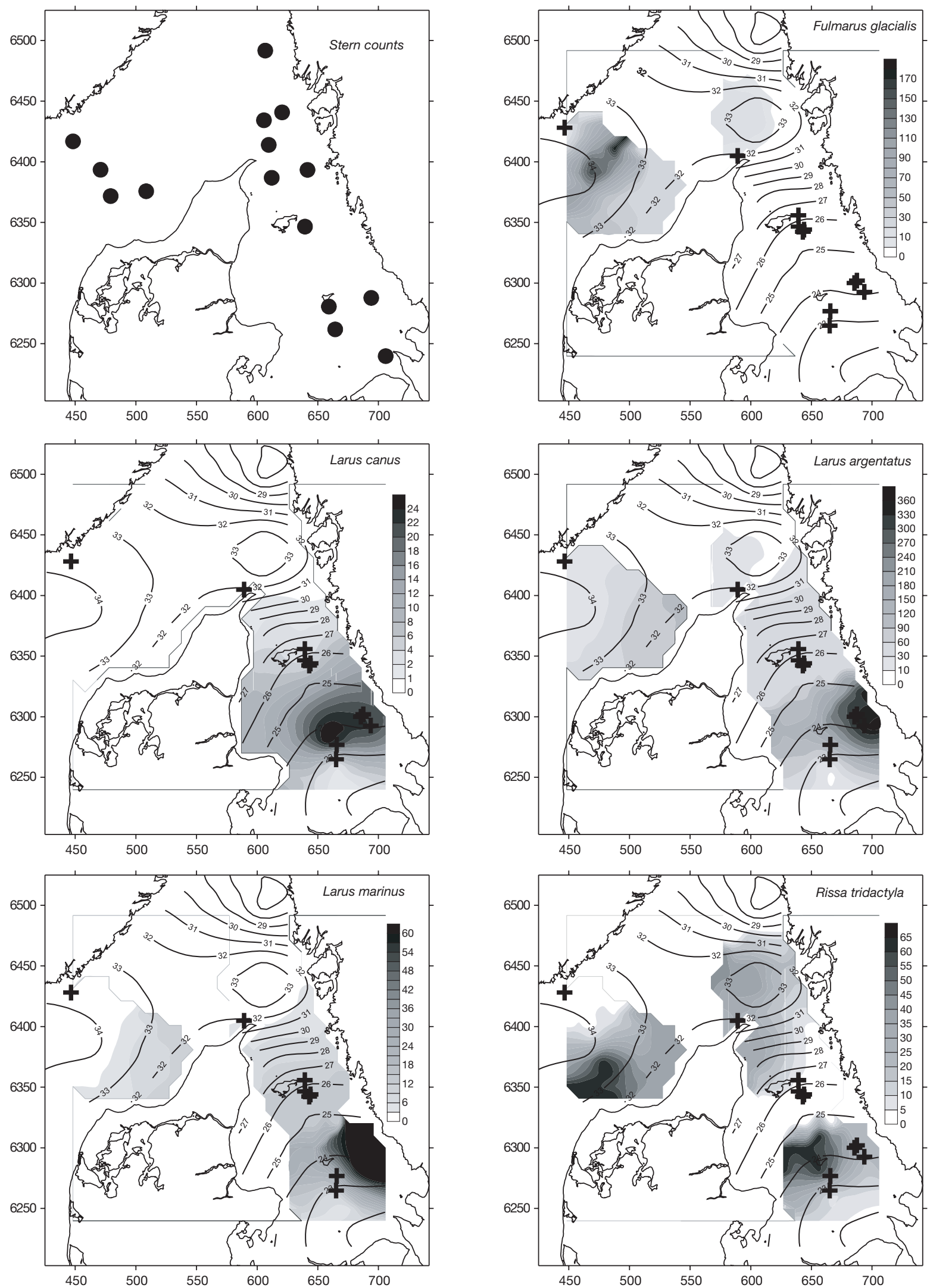

Fig. 4. Distribution of fulmars, common gulls, herring gulls, great black-backed gulls and kittiwakes attracted to the ship, and trawlers along the surface salinity gradient in the Skagerrak-Kattegat, Nov 94. (a) Black circles indicate trawl stations where stern counts were made. (b-f) Surface salinity (contour lines), number of scavenging seabirds recorded at the research ship (shaded contours) and active trawlers recorded within $3 \mathrm{n}$ mile (dark crosses). UTM coordinates, $\mathrm{km}$ 


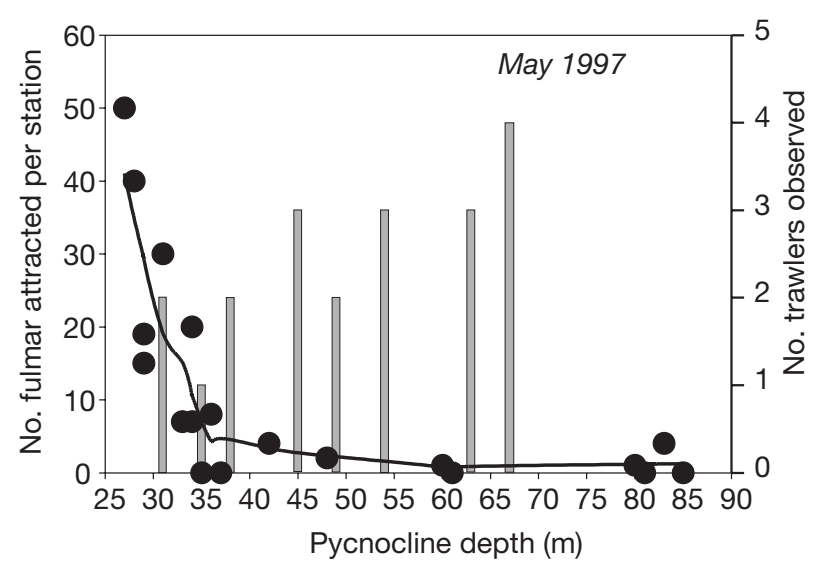

Fig. 5. Number of scavenging seabirds recorded at the research ship (black dots and LOWESS smoothed line) and number of active trawlers recorded within $2 \mathrm{n}$ mile (bars) in the Skagerrak, May 97, in relation to upwelling, as indicated by shallowing of the pycnocline

both species appeared in the southeastern Kattegat at around 23 to $24.5 \mathrm{psu}$ where trawlers were working, while fewer birds were attracted in trawler areas where salinity exceeded 26 psu. The pattern of kittiwake attendance was again different. No birds or low numbers of birds were attracted in the low-saline extreme southeastern corner of the Kattegat, in the central Kattegat, where several trawlers were observed, or in the northern part of the Skagerrak. However, high numbers of the species were observed on the shelf of the Skagerrak and in the central Kattegat. No clear overlap between peak numbers of attracted kittiwakes and the presence of trawlers was apparent. During the RV 'Dana' cruise in May 1997 it was possible to compare simultaneous observations of trawlers and attracted fulmars at different distances from the zone of maximum upwelling in the Skagerrak, with which this species is associated (Skov \& Durinck 1998, 1999). Although trawlers were mainly observed in areas characterised by a deep pycnocline, fulmars were only attracted in larger numbers in the parts of the Skagerrak where the pycnocline was shallower than $40 \mathrm{~m}$ (Fig. 5).

\section{DISCUSSION}

The modelled distribution of trawlers and attracted seabirds across oceanographic regimes in the Baltic Sea and the North Sea and the results obtained during test cruises indicate that the concurrence of fisheries and potentially scavenging seabirds is limited. We consider the spatial model to be robust, given the fact that the RV 'Argos' cruises covered the oceanographic gra- dient well, and that more than $700 \mathrm{n}$ mile of line transects were sampled during each of these cruises. Unfortunately, due to the lack of previous studies of the distribution of trawlers in the Skagerrak, Kattegat and the Baltic Sea, no judgements of longer-term characteristics of the regional dispersal of fisheries can be made. The diet of the 5 seabird species in the region during the non-breeding season is simply unknown, yet the discontinuities reported in the distribution of the 5 'scavenging' species of seabirds in relation to oceanographic regimes is in accordance with regional studies on seabird distributions at sea. Fulmar distribution in the region is characterised by low densities in low-saline waters and persistent peak densities in the zone of maximum upwelling in the Skagerrak, defined by the minimum depth of the pycnocline (Skov \& Durinck 1995, 1998, Skov et al. 1999). Our results, in particular the plot of the number of attracted fulmars in relation to the depth of the pycnocline (Fig. 5), indicate that the distribution of potentially scavenging fulmars agrees exactly with the distribution of fulmars observed away from trawlers. The dispersal of the other 4 species follows the same trend. Common gulls attracted to the ship were only frequently observed at stations in estuarine and coastal areas, which seem to comprise the most important habitat for wintering common gulls in the North Sea (Skov et al. 1995). In the Skagerrak-Kattegat, the range of large numbers of herring gulls, great black-backed gulls and kittiwakes spanned the distribution of nursing immature North Sea herring, and peak numbers were found within the 20 to $40 \mathrm{~m}$ depth zone of the mid shelf, where herring patches prevail (Skov et al. 2000). The 'normal' distribution of these 3 gull species does not deviate substantially from this pattern (Durinck et al. 1994, Skov et al. 1995, Laursen et al. 1997). Unlike the 2 larger species of gulls, kittiwakes were not attracted to the ship south of the range of North Sea herring, and not a single bird was seen at stations in the Baltic Sea. The absence of wintering kittiwakes in the Baltic Sea is a general feature found during all extensive surveys (Durinck et al. 1994, Laursen et al. 1997).

The pronounced variability in species composition of seabirds attracted to the ship, the small estimated attraction distances, the mismatch in the spatial variation of trawlers and seabirds and the fact that the distribution of potentially scavenging seabirds mirrors the 'normal' distribution of these species in the region, make us suggest that the interaction between trawlers and seabirds is a small-scale process. The existence of intra-specific correlations between birds attracted to the ship and birds recorded outside stations also indicates that the abundance of potential scavengers was determined primarily by coarse-scale processes related to hydrographic features and gradi- 
ents in the supply of natural foods, rather than by variability in the supply of fish waste from trawlers. The suggestion that fish waste from trawlers only offers seabirds supplementary food sources is in agreement with estimates of the proportion of scavengers near and away from trawlers, obtained during coordinated studies of scavenger abundance in the North Sea (Camphuysen et al. 1993, Camphuysen et al. 1995a). During these studies the proportion of birds near trawlers varied from 5 to $37 \%$ for fulmars, from 1 to $9 \%$ for gannets, 0 to $3 \%$ for great skuas Catharacta skua, 0 to $100 \%$ for common gulls, 0 to $55 \%$ for lesser black-backed gulls Larus fuscus, 0 to $83 \%$ for herring gulls, 6 to $25 \%$ for great blackbacked gulls and 1 to $25 \%$ for kittiwakes.

Processes such as the discarding of fish waste from working trawlers may resemble other small scale events attracting seabirds at sea, like the spill-over from feeding whales (Harrison 1979, Evans 1982) and increased availability of prey near flocks of other feeding seabirds (Cramp 1983). However, it remains to be shown whether the importance of such events to seabirds depends on location in relation to the boundaries of coarse scale marine habitats.

Does the local nature of potential scavenging as seen in this region challenge the common statements regarding the dependence of seabirds on discards (e.g. in the North Sea-Campuysen et al. 1995, Garthe et al. 1996)? By this hypothesis, dependence should control foraging strategies of scavenging seabirds at least during the non-breeding season, and we should expect gradients in their abundance towards areas with high rates of discards. During the breeding season, low availability of favourable 'natural' food may induce dependence on discards, and the phenomenon has been documented during the breeding season for great skuas (Furness 1987, Hamer et al. 1991), Audouin's gull Larus audouinii and yellow-legged gull Larus cachinnans (Oro et al. 1995a,b).

The mean attraction ranges estimated from feeding experiments during the Feb 93 International Bottom Trawl Surveys (IBTS) in the North Sea (Camphuysen et al. 1993) correspond well with the estimates obtained for the same species during this study. However, during both studies seabirds were attracted to research ships following IBTS trawling procedures and experimental discarding, which may be less effective than commercial trawlers, and thus result in underestimates of attraction ranges. Further underestimation of real attraction distances may be expected in situations where groups of trawlers are working within a smaller area. It is thus desirable to verify the results of this study for trawling activities over longer time scales (i.e. for fishing fleets working for prolonged periods in an area).
Our results underline that when the consumption of fish waste by seabirds is estimated irrespective of marine habitat, then an overestimate is likely for species with strong habitat affinities. If a local response to variability in fishing effort is a general phenomenon in the ecology of non-breeding seabirds, then earlier estimates of seabirds' consumption of discards are biased and should be used with caution (Garthe et al. 1996, Tasker \& Furness 1996). Assessments of the proportion of seabird populations that regularly uses discards and offal require realistic small-scale estimates of seabirds' total consumption rates as a basis for judgements on the impact of changes in fishing practices on seabird populations. The fact that seabirds' use of fish waste is inversely correlated with the availability of natural prey (Hamer et al. 1991, Walsh et al. 1991, Camphuysen et al. 1995a) also shows the need to estimate seabirds' consumption of natural/man-made foods in 'normal' as well as in 'emergency' situations. In order to improve our advice on future fishing practices we need to expand our knowledge of the habitat requirements and basic diets of potential scavengers considerably. The fact that knowledge of natural food selection is virtually non-existent for many areas of the nonbreeding range of potential scavengers on the Northwest European Shelf emphasises the research effort required if we want to achieve a more elaborate understanding of the role of seabirds in the marine ecosystem.

Acknowledgements. ICES (International Council for the Exploration of the Sea) kindly provided data on distribution of young fish from the 'International Young Fish Survey' and the 'International Bottom Trawl Survey' databases. The hydrographic data for this study were supplied by The Oceanographical Laboratory of the Swedish Meteorological and Hydrological Institute, the ICES Oceanographic Data Centre and the Danish Fisheries Research Institute. We also wish to thank the cruise leaders and crews onboard RV 'Argos' and RV 'Dana' for their co-operation. Financial support for this study was granted by the Swedish World Wide Fund for Nature, the European Commission (EC DG XIV research contracts 92/3505 and BIOECO/93/10) and the Scientific Committee of the Danish Ornithological Society.

\section{LITERATURE CITED}

Abrams RW (1985) Pelagic seabird community structure in the Southern Benguela region: changes in response to man's activities? Biol Conserv 32:33-49

Anonymous (1992) Manual for the International Bottom Trawl Surveys. ICES CM 1992/H:3

Boswall J (1960) Observations on the use by sea-birds of human fishing activities. Br Birds 53:212-215

Brown RGB (1970) Fulmar distribution: a Canadian perspective. Ibis 112:44-51

Camphuysen CJ, Garthe S (1997) An evaluation of the distribution and scavenging habits of northern fulmars (Fulmarus glacialis) in the North Sea. In: Blaxter JHS, Ramster JW, 
Smith SJ, Reid JB (eds) Seabirds in the marine environment. Proc ICES Int Symp, 22-24 November 1996, Glasgow, ICES Mar Sci Symp 204 / ICES J Mar Sci 54(4):654-684

Camphuysen CJ, Ensor K, Furness RW, Garthe S, Hüppop O, Leaper G, Offringa H, Tasker ML (1993) Seabirds feeding on discards in winter in the North Sea. EC DG XIV research contract 92/3505. NIOZ Rapport 1993-8, Netherlands Institute for Sea Research, Texel

Camphuysen CJ, Calvo B, Durinck J, Ensor K, Follestad A, Furness RW, Garthe S, Leaper G, Skov H, Tasker ML, Winter CJN (1995a) Consumption of discards by seabirds in the North Sea. Final Report EC DG XIV, research contract BIOECO/93/10. NIOZ report 1995

Camphuysen CJ, Heessen HJL, Winter CJN (1995b) Distant feeding and associations with cetaceans of gannets Morus bassanus from the Bass Rock, May 1994. Seabird 17:36-43

Cramp C (ed) (1983) The birds of the Western Palearctic, Vol III. Oxford University Press, Oxford

Durinck J, Skov H, Danielsen F (1990) Some factors determining seabird distribution in the North Sea. In: Madsen J (ed) Proc 7 Nordic Orn Congr, Danish Ministry of Environment, Copenhagen, p 9-17

Durinck J, Skov H, Danielsen F (1991) Winter food of guillemots Uria aalge in the Skagerrak. Dan Ornitol Foren Tidsskr 85:145-151 (in Danish with a summary in English)

Durinck J, Skov H, Jensen FP, Pihl S (1994) Important marine areas for wintering birds in the Baltic Sea. EU DG XI research contract 2242/90-09-01. Ornis Consult report

Evans PGH (1982) Associations between seabirds and cetaceans: a review. Mammal Rev 12(4):187-206

Furness RW (1987) The skuas. T \& AD Poyser, Calton

Furness RW (1992) Implications of changes in net mesh size, fishing effort and minimum landing size regulations in the North Sea for seabird populations. JNCC Rep 133

Garthe S (1993) Quantifizierung von Abfall und Beifang der Fischerei in der südöstlichen Nordsee und deren Nutzung durch Seevögel. Hamburger Avifaun Beitr 25:125-237

Garthe S, Camphuysen CJ, Furness RW (1996) Amounts of discards by commercial fisheries and their significance as food for seabirds in the North Sea. Mar Ecol Prog Ser 136:1-11

Hamer KC, Furness RW, Caldow RWG (1991) The effects of changes in food availability on the breeding ecology of great skuas Catharacta skua in Shetland. J Zool 223: 175-188

Harrison CS (1979) The association of marine birds and feeding gray whales. Condor 81:93-95

Hognestad PT (1987) Assessment of the environmental conditions in the Skagerrak and Kattegat. ICES Coop Res Rep 149

Hudson AV, Furness RW (1988) Utilization of discarded fish by scavenging seabirds behind white fish trawlers in Shetland. J Zool 215:151-166

ICES (1996) Manual for the International Bottom Trawl Surveys. ICES CM 1996/H:1

Kullenberg G (1981) Physical oceanography. In: Voipio A (ed) The Baltic Sea. Elsevier Oceanography Series 30, Elsevier, Amsterdam, p 54-86

Laake JL, Buckland ST, Anderson DR, Burnham KP (1993)

Editorial responsibility: Otto Kinne (Editor),

Oldendorf/Luhe, Germany
DISTANCE User's Guide v2.0. Colorado Cooperative Fish \& Wildlife Research Unit, Colorado State University, Fort Collins, CO

Laursen K, Pihl S, Durinck J, Hansen M, Skov H, Frikke J, Danielsen F (1997) The numbers and distribution of waterfowl in Denmark 1987-1989. Dan Rev Game Biol 15(1): $1-181$

Lee AJ (1980) North Sea: physical oceanography. In: Banner FT, Collins MB, Massie KS (eds) The sea and the sea bed in motion. Elsevier Oceanography Series 24B, Elsevier, Amsterdam, p 467-493

Madsen FJ (1957) On the food habits of some fish-eating birds in Denmark. Dan Rev Game Biol 3(2):19-83

Munk P, Christensen V (1990). Larval growth and drift pattern and the separation of herring spawning groups in the North Sea. J Fish Biol 37:135-148

Oro D, Bosch M, Ruiz X (1995a) Effects of a trawling moratorium on the breeding success of the yellow-legged gull Larus cachinnans. Ibis 137:547-549

Oro D, Jover L, Ruiz X (1995b) Effects of trawl moratorium on some breeding parameters of Audouin's gull Larus audouinnii in the Ebro Delta, NE Spain. In: Tasker ML (ed) Threats to seabirds. Proc 5th Int Seabird Group Conf, Glasgow Seabird Group, Sandy, p 33

Skov H, Durinck J, Leopold MF, Tasker ML (1995) Important bird areas for seabirds in the North Sea, including the Channel and Kattegat. BirdLife International, Cambridge

Skov H, Durinck J (1998) Constancy of frontal aggregations of seabirds at the shelf break in the Skagerrak. J Sea Res 39:305-311

Skov H, Durinck J (1999) Seabird distribution in relation to hydrography in the Skagerrak. Cont Shelf Res 20:169-187

Skov H, Durinck J, Andell P (2000) Associations between wintering avian predators and schooling fish in the Skagerrak-Kattegat suggest reliance on predictable aggregations of herring Clupea harengus. J Avian Biol 31:135-143

Tasker ML, Becker PH (1992) Influences of human activities on seabird populations in the North Sea. Neth J Aquat Ecol 26(1):59-73

Tasker M, Furness RW (1996) Estimation of food consumption by seabirds in the North Sea. In: Hunt GL, Furness RW (eds) Seabird/fish interactions, with particular reference to seabirds in the North Sea. ICES Coop Res Rep 216, p 6-42

Tasker ML, Jones PH, Dixon TJ, Blake, BF (1984) Counting seabirds at sea from ships: a review of methods employed and a suggestion for a standardised approach. Auk 101: 567-577

Thompson KR (1992) Quantitative analysis of the use of discards from squid trawlers by black-browed albatrosses Diomedea melanophris in the vicinity of the Falkland Islands. Ibis 134:11-21

Walsh PM, Sears J, Heubeck M (1991) Seabird numbers and breeding success in 1990. NCC Chief Sc Dir Rep 1235, Nature Conservancy Council, Aberdeen

Webb A, Durinck J (1992) Counting birds from ship. In: Komdeur J, Bertelsen J, Cracknell G (eds) Manual for aeroplane and ship surveys of waterfowl and seabirds, IWRB Spec Publ 19, p 24-37

Submitted: April 28, 1999; Accepted: October 26, 2000

Proofs received from author(s): April 16, 2001 